\title{
Thematic irony in the story of Susanna
}

\begin{tabular}{|c|c|}
\hline \multicolumn{2}{|c|}{$\begin{array}{l}\text { Author: } \\
\text { Dichk M. Kanonge }^{1}\end{array}$} \\
\hline \multicolumn{2}{|c|}{$\begin{array}{l}\text { Affiliation: } \\
{ }^{1} \text { Faculty of Theology, } \\
\text { North-West University, } \\
\text { Potchefstroom Campus, } \\
\text { South Africa }\end{array}$} \\
\hline \multicolumn{2}{|c|}{$\begin{array}{l}\text { Note: } \\
\text { This article was part of the } \\
\text { third chapter of the author's } \\
\text { PhD thesis presented at the } \\
\text { Potchefstroom Campus of } \\
\text { the North-West University } \\
\text { (South Africa) in 2009. The } \\
\text { text of Susanna that will be } \\
\text { used here is essentially the } \\
\text { Theodotion version. This } \\
\text { version has a most elaborate } \\
\text { narrative focussing more } \\
\text { on Susanna than the LXX } \\
\text { does. The author is currently } \\
\text { a post-doctoral fellow at } \\
\text { North-West University. }\end{array}$} \\
\hline \multicolumn{2}{|c|}{$\begin{array}{l}\text { Correspondence to: } \\
\text { Dichk Kanonge }\end{array}$} \\
\hline \multicolumn{2}{|c|}{$\begin{array}{l}\text { Email: } \\
\text { dickmwamba@yahoo.fr }\end{array}$} \\
\hline \multicolumn{2}{|c|}{$\begin{array}{l}\text { Postal address: } \\
112 \text { Molen Street, } \\
\text { NoordBrug 2531, } \\
\text { South Africa }\end{array}$} \\
\hline \multicolumn{2}{|c|}{$\begin{array}{l}\text { Dates: } \\
\text { Received: } 10 \text { Apr. } 2012 \\
\text { Accepted: } 11 \text { Sept. } 2012 \\
\text { Published: } 01 \text { Mar. } 2013\end{array}$} \\
\hline \multicolumn{2}{|c|}{$\begin{array}{l}\text { How to cite this article: } \\
\text { Kanonge, D.M., 2013, } \\
\text { 'Thematic irony in the story } \\
\text { of Susanna', HTS Teologiese } \\
\text { Studies/Theological Studies } \\
69(1), \text { Art. \#1255, } 6 \text { pages. } \\
\text { http://dx.doi.org/10.4102/ } \\
\text { hts.v69i1.1255 }\end{array}$} \\
\hline \multicolumn{2}{|c|}{$\begin{array}{l}\text { Copyright: } \\
\text { (C) 2013. The Authors. } \\
\text { Licensee: AOSIS } \\
\text { OpenJournals. This work } \\
\text { is licensed under the } \\
\text { Creative Commons } \\
\text { Attribution License. }\end{array}$} \\
\hline \multicolumn{2}{|l|}{ Read online: } \\
\hline 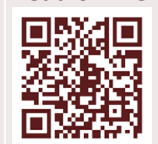 & $\begin{array}{l}\text { Scan this QR } \\
\text { code with your } \\
\text { smart phone or } \\
\text { mobile device } \\
\text { to read online. }\end{array}$ \\
\hline
\end{tabular}

It is commonly held that irony features significantly in Susanna. This seemingly plausible hypothesis, however, has not yet been supported by compelling evidence resulting from a systematic analysis of Susanna. This study attempts to fill this gap by investigating the main ironic expressions, words and incidents featuring in Susanna. The approach followed consists of uncovering expressions of irony embedded in the story by paying attention to ironic use of metaphor, ironic use of wordplay, ironic use of rhetorical questions, ironic understatements (e.g. litotes), ironic exaggeration (e.g. hyperbole), ironic use of social conventions and traditions and ironic attribution. It is the contention of this study that Susanna is a thematically ironic story. The use of reversed social conventions is the most powerful and the most abundant expression of irony in the story. This dominant derisive technique is possibly aimed at addressing the irrelevance as well as the abuse of Jewish social conventions in the Second Temple period.

\section{Introduction}

This article investigates the occurrence of irony in the story of Susanna. Scholars assume that Susanna ${ }^{1}$ is highly ironic in its content as well as in the structure of its plot (cf. Clanton 2006:56, 57, 58, 64, 67, 75, 81, 83, 85; Dunn 1982:19-31; Gruen 1998; Haag et al. 1994:238; Kay 1913:642). Despite this scholarly awareness of the prevalence of irony as a literary phenomenon in the narrative, the topic nevertheless remains under-researched. Whilst for the most part the abovementioned scholars have been content to note considerable instances of irony in Susanna, typically in footnotes, no full-scale study on the emergence of this literary device in the narrative exists. The purpose of this contribution is to fill the gap by pointing out various types of irony embedded in the story of Susanna. The study will not consider the emplotment of the story since this aspect of the story merits an in-depth investigation of its own. Only ironic words, expressions and incidents emerging from the content of the story will be examined.

The main techniques of irony that are available to authors and that will be followed by this study include the ironic use of metaphor, the ironic attribution, the ironic use of various kinds of wordplay, the ironic use of rhetorical questions, the ironic understatements (e.g. litotes), the ironic exaggeration (e.g. hyperbole) and the ironic use of social conventions and traditions (cf. Good 1981:129; Tubbs 1990:134-135; Shelly 1992:134). Ironic statements and incidents featuring in Susanna are mapped out below according to these techniques.

\section{Concerning the extent of irony in a literary work, Good (1981) argues that:}

[i]rony may take several forms. It may be a punctual irony, the use of words and expressions of ironic intention at particular, more or less isolated, 'points.' It may be episodic irony, the perception of an entire episode with an ironic aim or content. It may be the thematic irony, the conjunction of a number of episodes all of which point to an ironic theme or motif. (pp. 81-82)

Good's contention reveals that the proportion of irony differs from one text to another. Whilst incidental irony may exist in many literary works, in some, however, irony constitutes the main communicative strategy exploited by an author to highlight a specific motif. The contention of this endeavour is that irony is not incidental to the message of Susanna. It seems to depict a technique through which the author chose to pass his message to his community. Therefore, Susanna can be considered as a thematically ironic narrative. The use of overturned social conventions appears to be the most powerful and the most abundant ironic expression in the story. This dominant ironic technique is possibly aimed at emphasising the irrelevance as well as the distortion of social conventions.

The article does not pretend to be an exhaustive presentation of all ironic expressions found in the story. Instead, only the most relevant of them are identified and discussed.

1.In this study, Susanna (italicised) refers to the story of Susanna whilst Susanna (non-italicised) refers to its female protagonist. The apocryphal story of Susanna is an addition found at the end of the Greek book of Daniel in the LXX (cf. ch. 13). The LXX Greek text is quoted from Rahlfs' (1996) edition of the LXX. 


\section{The analysis}

As indicated above, this study investigates the emergence of ironic words, expressions or incidents in Susanna. For the sake of an efficient investigation, the story is segmented as follows into four sequences or episodes (Kanonge 2009b:380).

\section{Ironic expressions in episode one (vv. 1-14)}

This first episode consists of the introduction to Susanna (1-4), which includes the introduction of her family, her husband and the two elders (5-6), as well as the emergence of the conflict (7-14). In particular, it focuses on Susanna's beauty and godliness on the one hand and the elders' wickedness on the other hand. In this comparison lies the irony. The episode contains, as will be demonstrated shortly, remarkable ironic words, expressions and incidents. Most of these ironic utterances consist of the reversed use of social conventions.

The first ironic expression concerns the relationship between Susanna and her husband, expressed by the verb $\lambda \alpha \mu \beta \alpha \dot{v} \omega$ [to take, to acquire] (cf. v. 2). There is no doubt that, in the context of the ancient Jewish patriarchal society, this verb portrays a marital relationship between husband and wife in terms of possessor and possession (Di Lella 1984:332-334, 1995:39; see also Liddell \& Scott 1996:1026; Delling 2000:5; Bauer et al. 2000:583). In this environment, $\lambda \alpha \mu \beta \alpha ́ v \omega$ would normally indicate the ascendancy of the husband over his wife and presupposes the insertion of the woman in her husband's family (Fuller 2001:339) and not the contrary.

The use of $\lambda \alpha \mu \beta \alpha \dot{v} \omega \omega$ in this case, however, seems to contradict these established patriarchal practices. In actual fact, the relationship between Susanna and her husband, as depicted in the story, does entail the prominence of the woman. Firstly, according to the story, Jewish identity is related to the practice of the Law of Moses, piety (Kanonge 2009a:381). It is strange that nothing is said about Joakim's piety. Besides, Susanna has a genealogy, or at least her father is named, but Joakim's father does not appear (Moore 1977:94). In Biblical traditions, 'genealogies can express social status, political power, economic strength, legal standing, ownership ...' (Wilson 1979:19). To have no genealogy is to be less important in a community. It seems, from this story and specifically from verse 63, that Susanna is more important in the community than her husband. In fact, according to the abovementioned verse (63), she is not inserted in her husband's family, but the contrary is assumed. According to Archer (Ilan 1993:55), women named after their father were either 'divorced or widowed'. This is not the case here. Indeed, Susanna is being prioritised here at the expense of her husband. It is remarkable that the normal familial order, as accepted in patriarchal societies, is

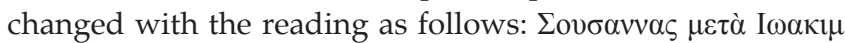

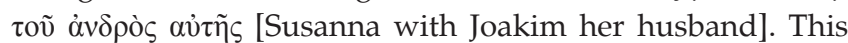
order is unusual in patriarchal traditions where the husband is supposed to take the lead in everything. There is an overturned use of social conventions.

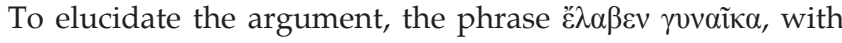
emphasis on the wife's family, is also found in 1 Kings 16:31 (Ahab and Jezebel). In both cases, a woman is taken,

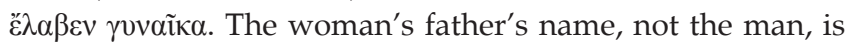
prominent. The woman's family is devoted to a deity. The woman is committed to the cult of her deity. Jezebel leads her husband and Israel to worship her deity. Susanna's fear of the Lord saves the Jewish community from corruption. In Ahab's account, $\check{\varepsilon} \lambda \alpha \beta \varepsilon v$ ironically means that Jezebel possessed Ahab and not the other way round. Her dominant character is underlined by many scholars (cf. Beeching 1980:587; Exum 1985:490; Crowley 1979:1893). Social conventions are used here to 'convey meaning opposite to that which they normally would have conveyed and in doing so exploits their ironic potential in communicating the message' (Shelley

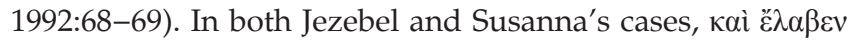

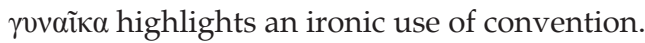

The combination of extreme beauty and implacable piety

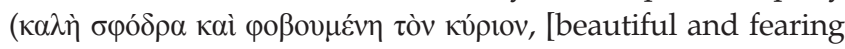
the Lord]) illustrates another ironic paradoxical use of social conventions in the story. The paradox is the coexistence of beauty (which entails sexual temptation) with piety (fear of the Lord) in Susanna. According to Jewish traditions, particularly the wisdom of Ben Sira, female 'beauty' ( $\kappa \dot{\alpha} \lambda \lambda \circ \varsigma_{\text {) }}$ is generally associated with sexual temptation (9:8; $25: 21$; $42: 12-14)$. It is assumed to be a potential threat to men's piety. In $42: 12-13$, for instance, Sira declares that ' $\pi \alpha v \tau \grave{~} \dot{\alpha} v \theta \rho \omega ́ \pi \omega$

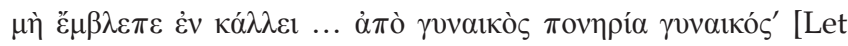
her not show her beauty (daughter) to any man ... woman's wickedness comes from woman nature]. Kó $\lambda \lambda \lambda_{0} \varsigma$ [beauty] is the key concept in this passage. Strikingly, here, beauty is linked to women's nature, from which comes wickedness

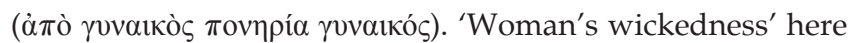
seems to refer to a woman's sexuality (Camp 1991:35; cf. also Trenchard 1982:158; Box 1913:471). The ironic flavour of this paradox of her combination of beauty and godliness is that this apparent deadly recipe in Susanna will result not in introducing wickedness (a role that will be ascribed to elders) but in the saving of the community from wickedness. That is a derisive use of social conventions to highlight their irrelevance.

A third example of irony in this first section of the text of Susanna is evident in the author's association of the elders with the introduction of wickedness in the Jewish community

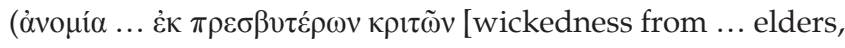
judges]). In contrast, Susanna is associated with godliness ( elders' wickedness whilst praising the virtue of a woman is an ironic use of social conventions. According to Jewish

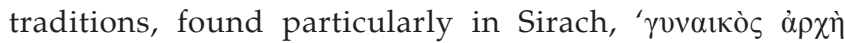

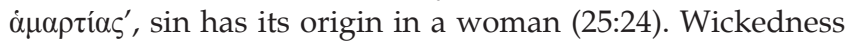
is singled out as an enduring attribute of women. The

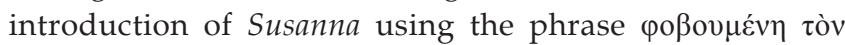
кúprov, as pointed out above, is not accidental. This feminine

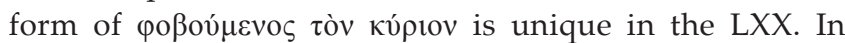
Greek, the present participle ( 
of the Lord not as a circumstantial trait but as a continual and enduring attribute of Susanna's character. This trait in Susanna goes against the conventions as outlined above and is clearly ironic. This is an ironic use of social conventions.

The author associates the elders with the introduction of

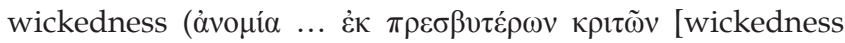
from ... elders, judges]), as said above. In Jewish tradition, however, elders were supposed to incarnate wisdom (Ben Sira 6:34). Yet, in the same tradition, wisdom and the fear of the Lord are considered to be inseparable (Pr 1:29). The fear of the Lord consists in the observation of the Law. In a converse of the convention regarding woman's inherent wickedness, the fear of the Lord as portrayed in Sira 6:30-36 should be the (male) elders' primary attribute. In fact, elders were believed to be 'custodians of the Law and its traditional interpretations (see Mt 15:2) and were charged with both its enforcement and the punishment of offenders' (Brauch 1988:680). Thus the association of wickedness with the elders entails the same ironic inversion of the conventional moral roles of men and women as in the previous paragraph. Ironic use of the social is also in view here.

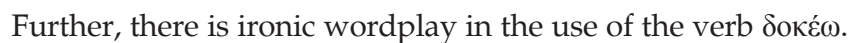
This Greek verb can be used for an established reputation or a reputation which is merely imaginary (Kittel 2000:233; Liddell \& Scott 1996:442). According to the last meaning, the elders were reputed or unquestionably honoured as genuine leaders by people, but in reality, they did not deserve it. This last connotation of $\delta$ oќ́ $\omega$ is unconventionally ironic.

The primary matter in episode 1 (1-14) is presented, as in many narratives, as protagonists challenging each other before the confrontation. This foreshadowing of conflict in this first section of the story also contains elements of irony.

Firstly, Susanna's daily walk in the garden (v. 7, 15) (a possible parallel to Gn 3:8) conveys an ambiguous message. In a society where women are assumed to be sexually insatiable, as discussed above, her promenade can be misinterpreted as a seductress's search for sexual satisfaction. Ben Sira, for example, urges fathers to watch their daughters diligently (26:10-12). According to him, a woman is like a

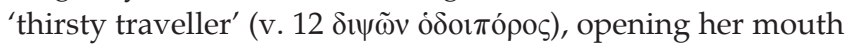

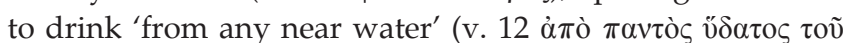

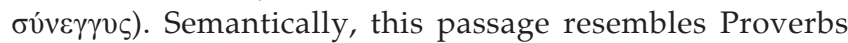

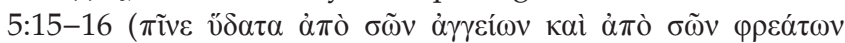

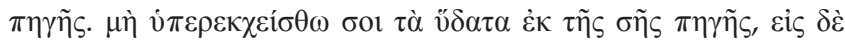

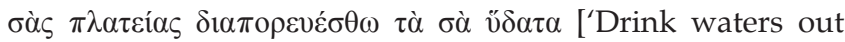
of your own cistern, and running waters out of your own well. Let not your fountains be dispersed abroad, and rivers of waters in the streets']). According to Loader (2009:211), 'drink water from your own cistern' (5:15) means 'engage in sexual relations with your own wife'. It is obvious from the comparison of the two texts that Sira (26:10-12) assumes that women are irresistibly greedy for sexual intercourse (cf. Berquist 2002:184). Susanna's daily walking in the garden, however, as proven by her rejection of the elders' advances, has nothing to do with sexual provocation. This is exactly why this biased judging of women will, ironically, constitute a deadly trap for the corrupted elders. That is rather ironically unconventional. Here again, an ironic use of social conventions is evident.

The second ironic expression relevant here is the metaphor

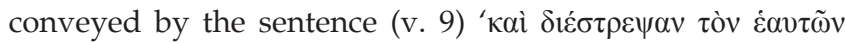

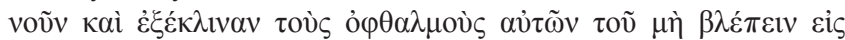

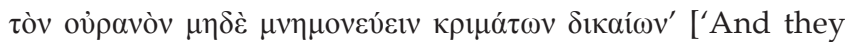
perverted their own mind, and turned away their eyes, that they might not look unto heaven, nor remember just judgments']. In this sentence, $\delta 1 \alpha \sigma \tau \rho \varepsilon \dot{\varphi} \varphi \omega$ [to pervert] and $\dot{\varepsilon} \kappa \kappa \lambda i$ iv $\omega$ [to turn away] are two key verbal metaphors. The first verb $(\delta 1 \alpha \sigma \tau \rho \varepsilon \dot{\varphi} \varphi \omega)$ occurs only about 35 times in the LXX (Ex 5:4; 23:6; Nm 15:39; Nm 32:7; Dt 32:5 Jdg 5:6; 3 Kingdoms 18:17; 3 Kingdoms 18:18; Ps 17:27; Odes 2:5; Pr 4:27a; Pr 6:14; Pr 8:13; Pr 10:9; Pr 11:20; Pr 16:30; Ec 1:15; Ec 7:13; Ec 12:3; Job 37:12; Sirach 11:34; Sirach 19:25; Sirach 27:23; Psalms of Solomon 10:3; Mi 3:9; Hab 1:4; Is 59:8; Ezk 13:18; Ezk 13:22; Ezk 16:34; Susanna 9; Susanna 56). The meaning of this verb depends on the context in which it is used. It is not the intention here to exhaustively explore all the contexts in which the word occurs in the LXX. Here in Susanna, this verb means 'to cause to depart from an accepted standard of moral or spiritual values, make crooked, pervert' (Bauer et al. 2000:237). As in Deuteronomy 32:5, $\delta 1 \alpha \sigma \tau \rho \varepsilon \dot{\varphi} \omega$ is used here in the context of perversion and rejection of the relationship with God, established by election and covenant (Merrill 2001:410-411; cf. Smith 1993). As Morris (1988:167)

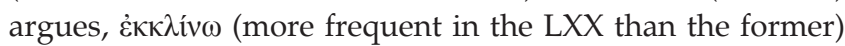
is a 'strong one and certainly means more than an accidental missing a way'. It implies, as Newman and Nida (1994:60) suggest, that the two elders 'do not wish to have God in their minds,' 'will not remember God any longer,' or 'have turned their backs on God'.

Put together, these two verbs of action, conjugated in an active voice, emphasise the elder's active determination to reject the Jewish God and the Law and their deliberate resolution to persevere in wickedness. This evil determination is totally incompatible with the Law of Moses. The latter is supposed to be the rule of conduct in the Jewish community. Moreover, the Law is the foundation of the just judgement in the Jewish community. That the anti-Law who has already rejected God, namely the two corrupted elders, could become judges in Israel (a theocratic community) illustrates an ironic distortion of social conventions.

The last part of the first episode is also very ironic (13-14). Firstly, the elders' sexual lust was so strong that it prevented them from going home for lunch (v. 13). In Jewish traditions, abstention from food (also known as fasting) has the purpose of repenting from sin (cf. the book of Jonas), not preparing for it. In addition, verse 14 presents the elders as 'judging'

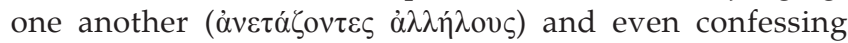

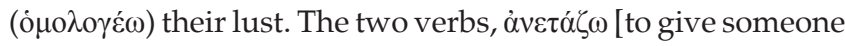
a judicial hearing (Bauer et al. 2000:78; Liddell \& Scott

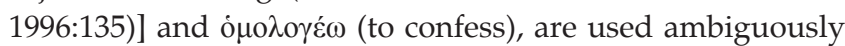
and thus ironically. Whilst the first verb refers to a judicial hearing which possibly entails a punishment (Bauer et al. 
2000:78), ó $\mu \mathrm{o} \lambda \mathrm{o} \varepsilon \dot{\varepsilon} \omega$ [denoting confession] would have meant changing their intention, not agreeing to support one another in their evil endeavour (Michel 2000:200). In this part of the episode, the reversed use of social convention is also evident.

The above analysis reveals that irony plays a very important role in the flow of this first section. It is not incidental; it controls the structure of the entire episode. Irony here, as revealed above, consists mainly in the reversed use of social conventions.

The following section examines ironic expressions in the second episode.

\section{Ironic expressions in episode two (vv. 15-28)}

This episode (15-27) focuses on the encounter between Susanna and the elders in the garden. The elders demanded sexual intercourse with Susanna. If she refused, she would face an accusation of adultery with a certain young man. Susanna rejects the elders' demand and, as a consequence, the elders promise to carry out their threat. There is irony to be found in all stages of this section of story

Firstly, verse 15 states that Susanna 'desired to bath in the

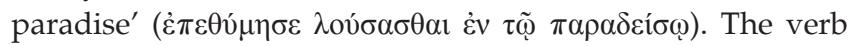
$\dot{\varepsilon} \pi \imath v 0 \mu \dot{\varepsilon} \omega$ (15), which characterises Susanna's desire for bathing, and the noun $\dot{\varepsilon} \pi \imath v \mu i \dot{\alpha}$, which characterises the elders' sexual lust, stem from the same root. In Ancient Greece, it denoted sexual desire (Büchsel 2000:168). As has already been argued in a thesis on Susanna (Kanonge 2009b), in this narrative, the substantive $\dot{\varepsilon} \pi \imath 0 \mu$ í $\alpha$ denotes sexual appetite and always refers to the elders. However, $\dot{\varepsilon} \pi \imath \theta v \mu \varepsilon \dot{\varepsilon} \omega$, as related to Susanna, is free from this connotation. The irony resides precisely in this unconventional and ambiguous use of the word.

The second ironical expression is the contrast between the elders and Susanna concerning the concept 'wickedness'.

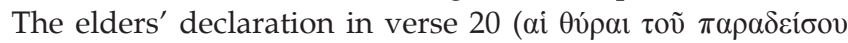

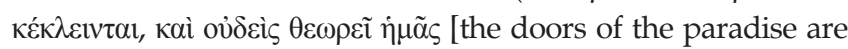
closed and no one watches us]) reveals that God's presence means nothing to them, but it does mean much to Susanna

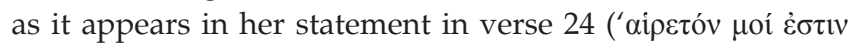

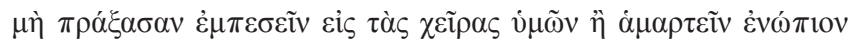
$\kappa v \rho i ́ o v '$ ['it is better for me to fall into your hands, and not do it, than to sin in the sight of the Lord']). In the elders' view, wickedness always depends on the presence of men not on the presence of God. However, these two men, being elders, should have been responsible for bringing awareness of God's presence into the community. Their behaviour is inappropriate for the leaders of a theocratic community and is ironic in its strangeness.

The third expression of irony is attributive irony. The elders' intention is to ridicule Susanna and her fear of the Lord if she refuses to satisfy their demand. To reach their objective, the elders threaten to formulate a false accusation against Susanna. They are thus aiming to attribute their own wickedness to Susanna. Their crying after Susanna reveals their intent. In Jewish traditions preserved in Deuteronomy 22:23-24:

${ }^{23}$ If a man happens to meet in a town a virgin pledged to be married and he sleeps with her, ${ }^{24}$ you shall take both of them to the gate of that town and stone them to death - the young woman because she was in a town and did not scream for help, and the man because he violated another man's wife. You must purge the evil from among you.

Confusingly, however, not only does Susanna scream for help, but the two elders scream too. This attributive irony is shown in their twisting of justice, which unfortunately served their wicked purpose as they will be believed and consequently Susanna will be sentenced to death (v. 41). This twist of justice is an ironic use of Jewish social conventions.

Here again, irony is not punctual. It plays a very important role in the flow of this second episode as well. The twist of social conventions is the main ironic technique here as well.

\section{Ironic expressions in episode three (vv. 28-45)}

This third episode elaborates on the elders' achieving their threat by ironically attributing their wickedness to Susanna. The episode is also very ironic in the use of social conventions.

Firstly, the elders attribute their intention to a fictitious

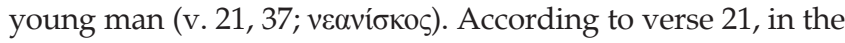
garden, the elders tell Susanna that, if she does not comply

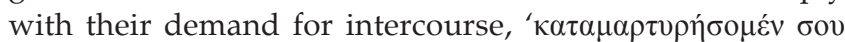

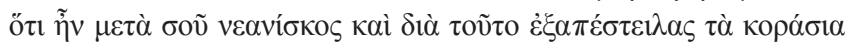
$\dot{\alpha} \pi$ ò $\sigma 0 \tilde{v}^{\prime}$ [We will testify against you that a young man was with you and for this reason you sent the maid far from you]. Verses 36-38 recount how the elders achieved their menace. According to these verses:

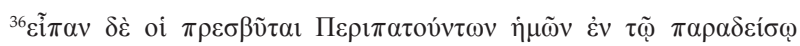

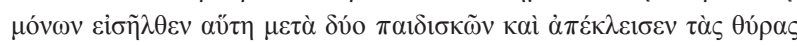

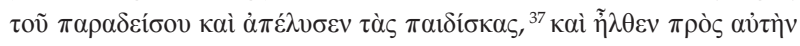

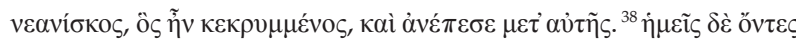

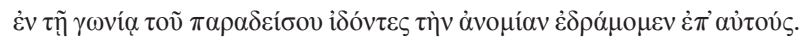 ['The elders said 'we were walking in the garden, she came in with two maids alone and she shut the doors of the garden and dismissed the maids; and a young man, who was hiding, came toward her and laid with her. And us being in the corner of the garden and seeing this wickedness, we ran toward them'.]

These verses reveal that the elders execute their threat to Susanna (v. 21). Their accusation against the young man was in fact attributing to him their own intention to have intercourse with her. The irony is extended in their apparent

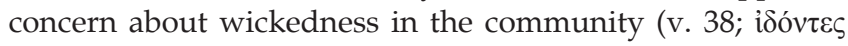

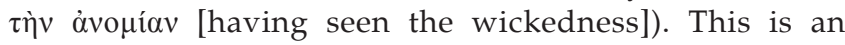
ironical attribution of wickedness to a chaste woman and a fictitious young man, by two wicked men, these alleged elders and judges in a Jewish community. This is ironically unconventional.

Secondly, the unveiling of Susanna (v. 32) by the elders as an alleged adulteress and the placing of hands (v. 34) on her is presented ironically as fulfilling the Law. In reality, however, the indirect satisfaction of the elders' sexual desire 
is the intended outcome of this action (ö $\pi \omega \varsigma \dot{\varepsilon} \mu \pi \lambda \eta \sigma \theta \tilde{\omega} \sigma \mathrm{IV} \tau \mathrm{ov}$ $\kappa \alpha ́ \lambda \lambda$ ov $\alpha$ $\tau \tilde{\tau} \varsigma$ [as being filled with her beauty]). As Collins (quoted by Clanton 2006) states:

the ritual of placing hands on the head occurs in three Contexts in the Bible: in the preparation of animals for sacrifice (Leviticus 8:14, 18, 22; Exodus 29:10, 16, 19); in the ritual of the scapegoat (Leviticus 16:21-22); and in the condemnation of blasphemers

(Leviticus 24:14). (p. 74)

None of these three concerns the punishment of adultery. As far as the community is concerned, the ritual is punishing Susanna's alleged adultery. The elders are aware, however, that Susanna is being punished for her chastity (Wills 1995:57) so that she serves now as their innocent scapegoat. The ironic twist of social conventions is strikingly evident here.

It is also evident that irony, noticeable in the overturned use of social conventions, is not incidental to this third episode but plays a very important role in its narrative.

\section{Ironic expressions in episode four (vv. 45-64)}

This last episode parallels the first (1-14). It contains the same elements as the first, but in the reverse sequence, and also uses various ironical expressions consisting mainly of reversed use of social conventions. For this study, only a few are relevant, as discussed here.

Firstly, the rejection of the condemnation of Susanna by a

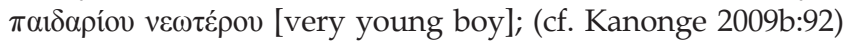
who questioned the judicial decision of the elders is a contemptuous use of social conventions. In fact, Daniel is

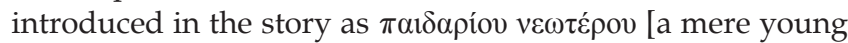
boy] (v. 45). The word $\pi \alpha 1 \delta \alpha \rho i ́ v$, with the adjunction of the

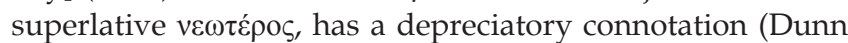
1982:25). It depicts Daniel as a 'little boy' (Liddell \& Scott 1996:1286) with no expertise in judicial affairs. The use of

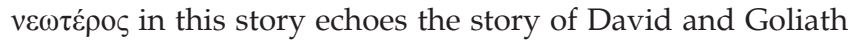
(1 Sm 17). In the latter story, Saul doubts David's capability to confront Goliath (1 Sm 17:32-33) as David is but a mere child.

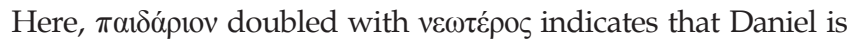
even younger than David and, thus, less experienced to judge as he did (Kanonge 2009b). Consequently, the recounting of this incident highlights an ironic use of social conventions.

Secondly, verse 48 consists of a rhetorical irony by means of

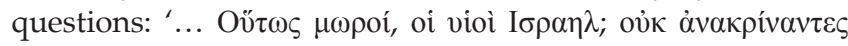

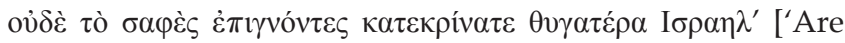
you so stupid, sons of Israel? Having neither examined closely, nor knowing the plain truth have you condemned the daughter of Israel?']. This verse goes together with

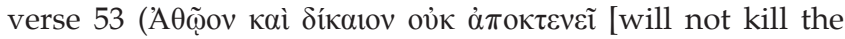
innocent and the righteous]) and echoes Exodus 23:1-9

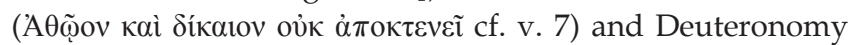
16:18-20. The two latter passages forbid perversion of justice in Jewish communities. The allusion to these two passages here illustrates also a distortion of Jewish judicial traditions. Jewish people, here, are manipulated and without 'critical examination or knowledge of the truth' (v. 48), they support the killing of an 'innocent and righteous' woman. There is no doubt here that social conventions suffer distortion.

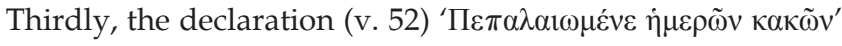
[waxen old in wickedness] is an ironic metaphorical use of social conventions because it presents a Jewish judge as a wicked man of old age, contrary to the tradition in Israel. One cannot be a judge, the incarnation of justice, and simultaneously grow incorrigible in wickedness.

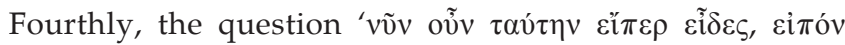

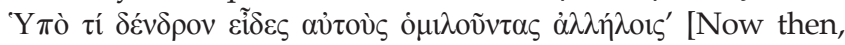
if thou saw her, tell me, under what tree did you see them companying together?] (54, cf. 58) is an example of rhetorical irony and is intended to ridicule the elders. It is assumed that they will not find a correct common answer to Daniel's question. The use of $\varepsilon i \pi \varepsilon \rho$ (if indeed or if really you saw them having intercourse) confirms this argument.

Fifthly, the words $\sigma \chi \tilde{i} v o v($ v. 54) and $\sigma \chi i$ isı (v. 55), on the one

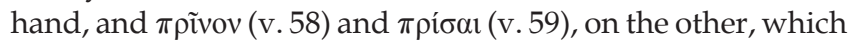
denote respectively the elders' answers to Daniel's questions and Daniel's reaction to these answers, constitute ironic wordplay. Daniel evokes the impending death of the elders in a mocking way by matching the sounds of their fictitious trees to the sounds of verbs implying God's punitive actions against them.

Sixthly, verse 56 abounds in ironic metaphors. The first is the

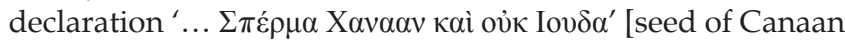
but not Judah]. The second ironic metaphor in this verse is

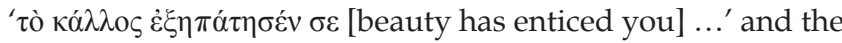

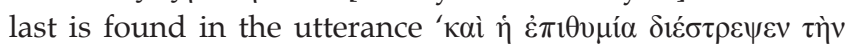
$\kappa \alpha \rho \delta i \alpha v \sigma o v^{\prime}$ [and the lust has distorted your heart]. All these examples are expressions of mockery.

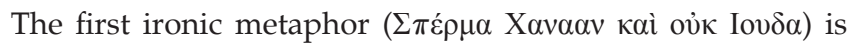
particularly biting as elders were considered guardians of Jewish identity and traditions (Bornkamm 2000:651-683). Here, however, they are ironically portrayed as seed of Canaan, germ of corruption. This is also an ironic use of social conventions.

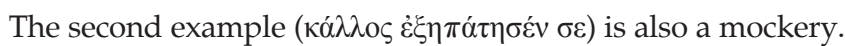
In the wisdom of Ben Sira (25:6), the glory of the elders is their fear of the Lord which is synonymous with hating wickedness (Pr 8:13). Here, they are enticed into wickedness

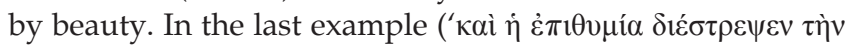

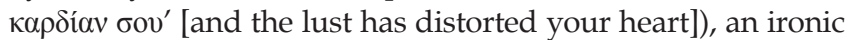
metaphor is used as a criticism: Instead of the fear of the Lord, the elders are characterised by lust. As in the preceding examples, Jewish social conventions are used ironically to highlight their abuse.

As demonstrated above, this episode is also systematically ironic. Irony consists mainly in the use of social conventions.

\section{Conclusion}

This study endeavoured to investigate the occurrence of irony in the story of Susanna. It was observed that despite the scholarly awareness of the existence of irony as a literary phenomenon in the narrative, the topic had not yet received due attention. Whilst for the most part, as said above, 
scholars have been content to note considerable instances of irony, typically in footnotes, no full-scale study on this trope in the narrative existed. This contribution was intended to fill this gap by pointing out instances of irony embedded in the story.

This main objective of the study was achieved by uncovering expressions of irony embedded in the story by paying attention to ironic use of metaphor, ironic use of wordplay, ironic use of rhetorical questions, ironic understatements (e.g. litotes), ironic exaggeration (e.g. hyperbole), ironic use of social conventions and traditions and the attributive use of irony. However, the study was not intended to deal with all the instances of irony in the story exhaustively. Instead, as said above, only some of the instances were discussed.

It transpired from the above discussions that Susanna is an essentially ironic story: Irony is not incidental in the narrative. It occurs in the structure of the story, in the derisive use of wordplay, in rhetorical questions, in metaphor and in the use of social conventions.

The use of overturned social conventions was found to be the most powerful and most abundant ironic expression in the story. This dominant technique is possibly aimed at highlighting the irrelevance as well as the abuse of social conventions amongst Jews of the Diaspora. On the one hand, sexist prejudices against women are ironically deemed irrelevant and thus strange to Jewish traditions and history. On the other hand, in an ironic way, the narrative addresses the attempt of certain Jews, namely the two elders, to adopt a Babylonian way of life at the expense of the Law.

There is no doubt that the author intentionally chose to pass his criticism of the behaviour of specific individuals within the story 'through a cleansing filter of irony', as in some ancient tragedies (Mitsis 1988:103-119). These characters, namely the two elders, have abused their positions within Jewish society, and a change in their behaviour is urged by the irony intrinsic to the story.

This study has tested and successfully confirmed the thesis that Susanna is a thematically ironic narrative.

\section{Acknowledgements Competing interests}

The author declares that he has no financial or personal relationship(s) that may have inappropriately influenced him in the writing of this article.

\section{References}

Bauer, W., Danker, F.W., Arndt, W. \& Gingrich, F.W. (eds), 2000, A Greek-English lexicon of the NewTestament and other early Christian literature, 3rd edn., University of Chicago Press, Chicago.

Beeching, M., 1980, s.v. 'Jezebel', in J.D. Douglas (ed.), New Bible dictionary, Inter-Varsity Press, Downers Grove, p. 587.

Berquist, J.L., 2002, Controlling corporeality: The body and the household in Ancient Israel, Rutgers University Press, Piscataway/London.

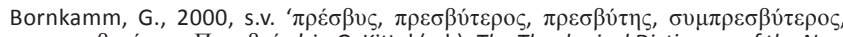
$\pi \rho \varepsilon \sigma \beta v \tau \varepsilon \dot{p} t o v, \Pi \rho \varepsilon \sigma \beta \varepsilon v \omega^{\prime}$ ', in G. Kittel (ed.), The Theological Dictionary of the New Testament, Eerdmans, Grand Rapids, vol. 6, pp. 651-683.
Box, G.H., 1913, 'Sirach', in R.H. Charles (ed.), The Apocrypha and Pseudepigrapha of the Old Testament, pp. 268-517, Clarendon Press, Oxford.

Brauch, MT., 1988, s.v. 'Elder', in W.A. Elwell \& B.J. Beitzel (eds.), Baker encyclopedia of the Bible, Baker Book House, Grand Rapids, pp. 679-681.

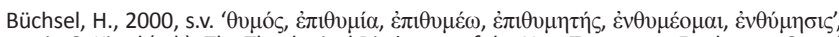
in G. Kittel (ed.), The Theological Dictionary of the New Testament, Eerdmans, Grand Rapids, vol. 3, pp. 166-172.

Camp, C., 1991, 'Understanding a patriarchy: Women in second-century Jerusalem through the eyes of Ben-Sira', in A-J. Levine (ed.), 'Women like this': New perspective on Jewish women, pp. 1-39, Scholars Press, Chico.

Clanton, D.W., 2006, The good, the bold, and the beautiful: The story of Susanna and its Renaissance interpretations, T\&T Clark, New York/London. PMCid:3449906

Crowley, E. 1979, s.v. 'Jezabel', in P.C. Meagher, T.C. O'Brien \& M.C. Aherne (eds.), Encyclopedic dictionary of religion, Corpus Publication, Washington, vol. F-N, p. 1893.

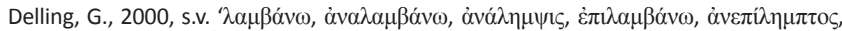

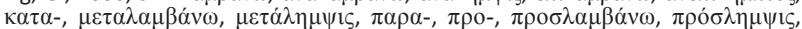
$\kappa \alpha \tau \alpha-$,
$\dot{v} \pi \mathrm{\alpha} \alpha \mu \beta_{\alpha} \alpha^{\prime} \omega^{\prime}$, in G.Kittel (ed.). The Theological Dictionary of New the Testament, Eerdmans, Grand Rapids, vol. 4, pp. 5-15.

Di Lella, A., 1984, 'WC Trenchard, Ben Sira's of Women: A Literary Analysis,' Catholic Biblical Quarterly 46, 332-334.

Di Lella, A., 1995, 'Women in the Wisdom of Ben Sira and the book of Judith: A study in contrasts and reversals', in J.A. Emerton (ed.), Vetus Testamentum, suppl. 61, pp. 39-52, Brill, Leiden.

Dunn, R., 1982, 'Discrimination in the Comic Spirit in the Story of Susanna', Christianity and Literature 31, 19-31.

Exum, J.C, 1985, s.v. 'Jezebel', in P.J. Achtemeier (ed.), Harper's Bible dictionary, Harper \& Row, San Francisco, p. 490.

Fuller, R., 2001, s.v. 'Marriage', in B.M. Metzger \& M.D. Coogan (eds.), The Oxford guide to ideas and issues of the Bible, Oxford University Press, Oxford, p. 3396

Good, E.M., 1981, Irony in the Old Testament, The Baker Book House and Almond Press, Sheffield.

Gruen, E.S., 1998, Heritage of Hellenism: The reinvention of Jewish tradition, University of California Press, Berkeley, Los Angeles/London.

Haag, H., Sölle, D., Kircheberger, J.H., Müller, A.M.S. \& Bührer, E., 1994, Great women of the Bible in art and literature, Eerdmans, Grand Rapids.

Ilan, T., 1995, Jewish women in the Greco-Roman period, Hendrickson Publishers, Peabody.

Kanonge, D.M., 2009a, 'Reading narratives in the Septuagint: A discourse on method', in J. Cook (ed.), Septuagint and reception, pp. 361-381, Vetus Testamentum, suppl. 127, Brill, Leiden.

Kanonge, D.M., 2009b, 'The emergence of women in the LXX Apocrypha: A semiotic study', PhD thesis, Deparment of Greek, North-West University.

Kay, D.M., 1913, 'Susanna', in R.C. Charles (ed.), The Apocrypha and Pseudepigrapha of the Old Testament, pp. 638-651, Clarendon Press, Oxford.

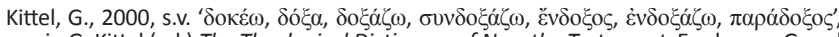
in G. Kittel (ed.) The Theological Dictionary of New the Testament, Eerdmans, Grand Rapids, vol. 2, pp. 232-254.

Liddell, H.G \& Scott, R. (eds.), 1996, A Greek-English lexicon with a supplement, Clarendon, Oxford.

Loader, W., 2009, 'The strange woman in Proverbs, LXX Proverbs and Aseneth', in J. Cook (ed.), Septuagint and Reception, pp. 209-227, Vetus Testamentum, suppl. 127, Brill, Leiden.

Merrill, E.H., 2001, Deuteronomy, the new American commentary, Broadman \& Holman Publishers, Nashville.

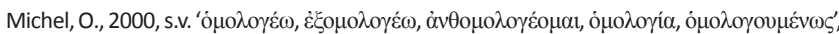
in G. Kittel (ed.), The Theological Dictionary of the New Testament, Eerdmans, Grand Rapids, vol. 5, pp. 199-219.

Mitsis, P., 1988, 'Xerxes' Entrance: Irony, myth, and history in the Persians', in P. Pucci (ed.), Language and the tragic hero, pp. 103-119, Scholars Press, Chico.

Moore, C.A., 1977, Daniel, Esther and Jeremiah: The additions, Doubleday \& Company, Garden City.

Morris, L., 1988, The epistle to the Romans, Eerdmans \& Inter-Varsity Press, Grand Rapids/Leicester.

Newman, B.M. \& Nida, E.A., 1994, A handbook on Paul's letter to the Romans: UBS handbook Series: Helps for translators, United Bible Societies, New York.

Rahlfs, A., 1996, Septuaginta: With morphology, Deutsche Bibelgesellschaft, Stuttgart. PMid:9013382

Shelly, P.J., 1992, 'Amos and irony: The use of irony in Amos's prophetic discourse', PhD thesis, Department of Old Testament, The Cliff School of Theology and the University of Denver.

Smith, J.E., 1993, The Pentateuch, 2nd edn., College Press, Joplin.

Tubbs, F.C., 1990, 'The nature and function of humor and wit in the Old Testament literary prophets', PhD thesis, Department of Old Testament, Southwestern Baptist Theological Seminary.

Trenchard, W.C., 1982, Ben Sira's view of women: A literary analysis, Scholars, Press, Chico. (Brown Judaic Studies, 38.)

Wills, L.M., 1995, The Jewish novel in the ancient world, Cornell University Press, Ithaca.

Wilson, R.R., 1979, 'Between 'Azel' and 'Azel' Interpreting the Biblical Genealogies', Biblical Archaeologist 43(Winter), 11-22. http://dx.doi.org/10.2307/3209544 